\title{
New species of rust fungi (Uredinales) from South Africa and new observations on known species
}

\author{
Reinhard Berndt
}

Received: 8 September 2008 /Revised: 19 December 2008/Accepted: 19 December 2008 / Published online: 23 January 2009

(C) German Mycological Society and Springer-Verlag 2009

\begin{abstract}
Four new species and a new variety of rust fungi (Uredinales) are described from South Africa: Puccinia montis-venenosi on Galium spurium ssp. africanum and $G$. tomentosum, P. naufraga on Helichrysum sp., Uredo fynbosense on Phylica oleifolia and Ph. buxifolia, Uromyces eclipsis on Zygophyllum morgsana, and Puccinia lycii var. bizonata on Lycium sp. Puccinia austro-africana is proposed as a new combination for P. tetragoniae var. austro-africana on Tetragonia. New observations are presented about already known species: The uredinial stage of Uromyces pentaschistidis is described; Uredo monechmatis is newly reported for South Africa on new hosts and its uredinial morphology is described; a detailed description is provided for the poorly known $P$. anthospermi; the identity of Uredo zygophylli, U. zygophyllina and Uromyces dinteri is discussed; a key is presented for the known Puccinia species on Helichrysum in South Africa.
\end{abstract}

Keywords Galium $\cdot$ Helichrysum $\cdot$ Phylica .

Rust mycobiota $\cdot$ Zygophyllum

\section{Introduction}

About 522 species of rust fungi have been reported from South Africa (Berndt 2008a), most of them by the South

$\overline{\text { Taxonomical novelties Puccinia austro-africana (Doidge) R. Berndt, }}$ Puccinia lycii Kalchbr. var. bizonata R. Berndt, Puccinia montis-venenosi R. Berndt, Puccinia naufraga R. Berndt, Uredo fynbosense R. Berndt, Uromyces eclipsis R. Berndt \& A. R. Wood

R. Berndt $(\bowtie)$

ETH Zurich, Institute of Integrative Biology (IBZ),

CHN D-37, Universitätstr. 16,

8092 Zürich, Switzerland

e-mail: reinhard.berndt@env.ethz.ch
African mycologist Ethel Doidge (1950, and references therein). After Doidge, new species and reports were only published sporadically (e.g. Morris et al. 1988; Van Reenen 1995). In the last decade, South African rust fungi and their diversity and taxonomy have received more interest again and a considerable number of new species has been described recently (e.g. Berndt and Uhlmann 2006; Mennicken and Oberwinkler 2004; Wood 2006). Besides describing new species and findings, recent publications tended to present more comprehensive treatments of the rust species of certain host groups (e.g. Berndt 2008b; Mennicken et al. 2005; Wood 2007; Wood and Crous 2005).

In the present paper, four new species and a new variety of rust fungi are described and the taxonomic status and new observations of already known species are reported. The work is mainly based on collections made by A. Rössel, E. Uhlmann and the author in the Western Cape Province of South Africa in 2004 and 2005. The region has a prevalent winter rainfall regime and supports Fynbos, a heath-like shrubland, and Nama-karoo, an arid dwarf-shrub savannah, as major vegetation types (Cowling et al. 1997). Most of the collections were made in these vegetation types with some additional ones from coastal scrub and afromontane forest.

\section{Materials and methods}

Infected plant organs were observed with a Zeiss Stemi SV8 stereo microscope. Spore samples and hand sections were obtained from dried host specimens, mounted in lactophenol on a slide glass and gently heated. The preparations were examined either with a Zeiss 'Axiophot' compound microscope and photographs taken with a Zeiss 
'MC-80' camera on Kodak Ektachrome 64 Professional slide film or with an Olympus 'BX51' equipped with a 'ColorView IIIu' camera. In the latter case, the 'Cell*B' software package (Software Imaging System) was used to capture and edit micrographs and to measure details of spore walls and their ornament. Such measurements are given to $0.1 \mu \mathrm{m}$ while ordinary measurements made by the use of an ocular micrometer scale are given to $0.5 \mu \mathrm{m}$. Measurements were made on freshly embedded spores or sections. At least 30 spores were measured for each spore state; arithmetic means were calculated and are given in brackets (designated 'mean'). Names of herbaria were abbreviated by their acronyms according to Index Herbariorum (Holmgren et al. 1990). 'RSA' numbers are field collection numbers. The occurring spore states were listed designating the sori according to their position in the rust life cycle. Aecia are indicated by the Roman numeral I, uredinia by II, and telia by III.

The rust species are listed with their host families which are arranged alphabetically.

\section{Results and discussion}

Acanthaceae

Uredo monechmatis Cummins, new for South Africa on new host genera and species.

(Bull. Torrey bot. Cl. 79: 231. 1952. As U. monechmae).

Material examined: South Africa, Western Cape Prov., Knysna, Harkerville Forest, at 'Kranshoek walk', on Isoglossa ciliata (Nees) Lindau (RSA 70, II), Justicia capensis Thunb. (RSA 68, II) and cf. Hypoestes aristata (Vahl.) Sol. ex Roem. \& Schult. (without no., II) in coastal scrub forest, 26 Oct 2004, leg. R. Berndt and E. Uhlmann.

Rust fungi collected on members of Hypoestes, Isoglossa and Justicia in the afromontane and scrub forest of the Knysna region were identified as $U$. monechmatis based on characters of the urediniospores and the presence of a uredinial peridium with apical paraphyses (uredinia of Malupa-type). The urediniospores measured 22.5-28.5× 16.5-20 $\mu \mathrm{m}$ (mean $25.3 \times 18.6 \mu \mathrm{m}$ ) on Justicia capensis and $24-31 \times 17.5-21 \mu \mathrm{m}$ (mean $27.0 \times 19.3 \mu \mathrm{m})$ on Isoglossa ciliata. The plant determined as cf. Hypoestes aristata bore only a few uredinia with similar urediniospores that were not measured. U. monechmatis is only known so far on Monechma subsessile C.B. Clarke from Uganda (Laundon 1963a). A uredinial specimen on Dicliptera from Ethiopia listed by Laundon (1963a) is very similar to $U$. monechmatis and might belong to the latter. It has slightly smaller $(20-25 \times 15-19 \mu \mathrm{m})$ and more delicately echinulate urediniospores (Laundon 1963a).
The morphology of the uredinia (Malupa-type) and the pallid, thin-walled urediniospores indicate that $U$. monechmatis may be the uredinial state of a phakopsoraceous species. To my knowledge, this would be the first member of Phakopsoraceae on Acanthaceae. Isoglossa ciliata and Justicia capensis are new host genera and species for the present rust. Hypoestes may be an additional new host genus.

\section{Aizoaceae}

Puccinia austro-africana (Doidge) R. Berndt, a new combination for $P$. tetragoniae McAlpine var. austroafricana Doidge.

Material examined: P. tetragoniae var. tetragoniae. Australia, Victoria, Sandringham, on Tetragonia implexicoma (Miq.) Hook. f., leg. GH Robinson, Aug 1902, det. D. McAlpine (VPRI 4048a).

P. austro-africana (Doidge) R. Berndt, on Tetragonia sp. South Africa, Western Cape Prov.: Cape Peninsula, footpath between Cape Point Lighthouse and parking area, leg. E. Uhlmann and R. Berndt, 1 Nov 2004 (RSA 96, II/III). Vanrhynsdorp, at Vanrhynspass, slopes at lower section of pass road, $31^{\circ} 23^{\prime} 54.1^{\prime \prime} \mathrm{S}, 19^{\circ} 01^{\prime} 40.6^{\prime \prime} \mathrm{E}$, leg. A. Rössel, E. Uhlmann and R. Berndt, 11 Oct 2005 (RSA 156, II/III). Clanwilliam, road to Pakhuis Pass, $32^{\circ} 08^{\prime} 07.6^{\prime \prime} \mathrm{S}, 18^{\circ} 58^{\prime}$ 54.5"E, leg. A. Rössel, E. Uhlmann and R. Berndt, 13 Oct 2005 (RSA 194, II). Struisbaai, Cape Agulhas, 'Spookdraai'-hiking trail, coastal scrub within resort, 3449'24.0" S, $20^{\circ} 01^{\prime} 29.8^{\prime \prime}$, leg. A. Rössel, E. Uhlmann and R. Berndt, 30 Oct 2005 (RSA 399, II/III).

Puccinia tetragoniae was originally found in Australia on T. implexicoma with spermogonia, aecia, uredinia and telia (McAlpine 1906). The Puccinia occurring on Tetragonia in South Africa was recognized as a distinct variety within the latter species and named var. austro-africana by Doidge (1948). Our collections of P. tetragoniae made in several locations of the Western Cape Province tallied well with var. austro-africana as described by Doidge. A comparison with $P$. tetragoniae var. tetragoniae on the type host from Victoria, Australia (Fig. 1a-c), confirmed the differences between the varieties observed by Doidge (1948). Variety austro-africana (Fig. 1d-f) has smaller uredinio- and teliospores with thinner spore walls, especially in the urediniospores (Table 1). The known specimens bear only uredinia and telia in contrast to the macrocyclic $P$. tetragoniae var. tetragoniae.

In my opinion, the observable differences merit specific delimitation of var. austro-africana and I propose the new combination Puccinia austro-africana (Doidge) R. Berndt, comb. nov., based on $P$. tetragoniae var. austro-africana Doidge (Bothalia 4: 904/905. 1948. Type on T. expansa Thunb., PREM 34095). 
Fig. 1 a-c Puccinia tetragoniae (VPRI 4048a). d-f Puccinia austro-africana (RSA 399). Teliospores (a,d), urediniospores in optical section $(\mathbf{b}, \mathbf{e})$ and urediniospores with focus on spore surface $(\mathbf{c}, \mathbf{f})$. Asterisks indicate urediniospores of $P$. tetragoniae in which the indentation of the spore lumen is especially visible. It is less pronounced in $P$. austro-africana due to its thinner spore wall (arrows). Bars $=20 \mu \mathrm{m}$
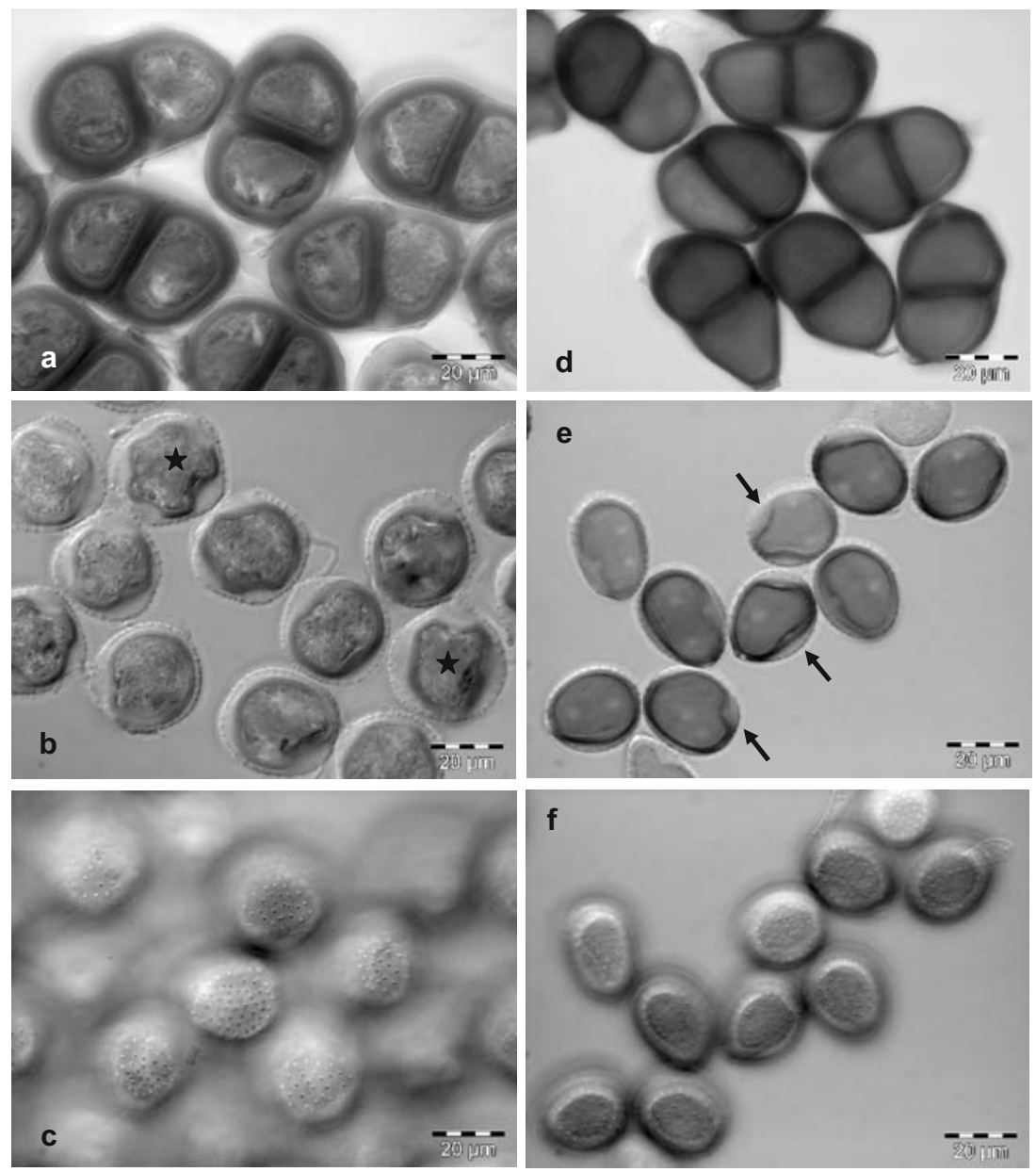

\section{Asteraceae}

\section{Puccinia on Helichrysum (Inuleae, Gnaphalinae)}

Doidge (1927) distinguished within P. kalchbrenneri De Toni a variety valida for specimens with longer teliospores and a more strongly thickened teliospore apex. Berndt and Uhlmann (2006) studied specimens of both varieties and observed that the characters intergraded. They concluded that P. kalchbrenneri was a variable species and that var. valida was not clearly distinguishable from var. kalchbrenneri.

New collections of P. kalchbrenneri from the Western Cape Province also varied considerably in several characters of the telio- and urediniospores. Differences were found with regard to the size of the teliospores and traits of their spore wall, the size of the urediniospores, the thickness and echinulation of their spore walls and the number and visibility of the germ pores. Despite the observable differences most of the specimens exhibited an overall similarity that did not allow clear distinguishing of separate morphs. One specimen was sufficiently different to warrant specific delimitation and is described as $P$. naufraga.
Puccinia naufraga R. Berndt, sp. nov.

Figures 2, 3 and 4.

Etymology: Named after the collection site, the 'Thomas Tucker Shipwreck Trail', Cape Peninsula.

Aecia singularia vel paucula in pagina abaxiali foliorum, peridio albo anguste cylindrico praedita; aeciosporae late ellipsoideae ad subglobosae, saepe leniter deformatae et subangulares, $23-32 \times 20-25 \mu \mathrm{m}(27.2 \times 22.5 \mu \mathrm{m})$, pariete hyalino vel subhyalino ca. $2 \mu \mathrm{m}$ crasso regulariter verruculoso, cellulae peridii intus verrucis irregularibus delicatis usque ad moderate grossis dense obsitae, extus fere leves vel papillosae verrucis planis et inconspicuis. Uredinia in pagina abaxiali foliorum sparsa, singularia vel aliquot aggregata, obscure brunnea basaliter atro-brunnea, cupulata, apertura centrali praedita, peridio cupuliformi e cellulis compressis paucistratis brunneis composito, copia sporarum cinnamomea vel ferruginea; urediniosporae subglobosae ad obovoideae, $23-28 \times 21-24 \mu \mathrm{m}(25.4 \times$ $22.6 \mu \mathrm{m})$, pariete ca. $1.5-2 \mu \mathrm{m}$ crasso inconspicue bilaminato, lamina exteriori angustissima subhyalina vel straminea regulariter echinulato spinis delicatis ca. 2-3 $\mu \mathrm{m}$ distantibus, lamina interiori crassiore dilute brunnea, poris 
Table 1 Characters of uredinio- and teliospores of Puccinia tetragoniae and P. austro-africana

\begin{tabular}{|c|c|c|}
\hline Species, specimen & Urediniospores (means) & Teliospores (means) \\
\hline P. tetragoniae (from McAlpine 1906) & $27-37 \times 22-25 \mu \mathrm{m}(31 \times 24 \mu \mathrm{m})$ & $40-60 \times 25-35 \mu \mathrm{m}(50 \times 30 \mu \mathrm{m})$ \\
\hline $\begin{array}{l}\text { P. tetragoniae (from Laundon 1963b, } \\
\text { sub var. tetragoniae) }\end{array}$ & $29-40 \times 27-39 \mu \mathrm{m}$, spore wall $3-7 \mu \mathrm{m}$ thick & $\begin{array}{l}40-60 \times 27-40 \mu \mathrm{m} \text {, spore wall } 2-5 \mu \mathrm{m} \text { thick, at } \\
\text { apex } 4-10 \mu \mathrm{m}\end{array}$ \\
\hline $\begin{array}{l}\text { P. tetragoniae Australia, Victoria } \\
\text { (VPRI 4048a) }\end{array}$ & $\begin{array}{l}30-34 \times 27-32 \mu \mathrm{m}(32.3 \times 29.1 \mu \mathrm{m}), \text { spore wall } 3- \\
4 \mu \mathrm{m} \text { thick, at germ pores } 7-8 \mu \mathrm{m} \text {, germ pores } \\
\text { scattered, } 7-10\end{array}$ & $\begin{array}{l}46-64 \times 29-40 \mu \mathrm{m}(54.1 \times 35.2 \mu \mathrm{m}) \text {, spore wall } \\
4-5.5 \mu \mathrm{m} \text { thick, at apex } 6-10 \mu \mathrm{m} \text {, pedicel more } \\
\text { or less persistent }\end{array}$ \\
\hline $\begin{array}{l}\text { P. tetragoniae (from Cunningham } \\
\text { 1931) }\end{array}$ & $\begin{array}{l}28-36 \times 22-28 \mu \mathrm{m}(30 \times 25 \mu \mathrm{m}) \text {, spore wall } 3 \mu \mathrm{m} \\
\text { thick, germ pores scattered, } 5-6\end{array}$ & $\begin{array}{l}52-60 \times 32-40 \mu \mathrm{m}(56 \times 36 \mu \mathrm{m}) \text {, spore wall to } \\
5 \mu \mathrm{m} \text { thick, at apex to } 8 \mu \mathrm{m} \text { or not thickened, } \\
\text { pedicel persistent }\end{array}$ \\
\hline $\begin{array}{l}\text { P. austro-africana (from Doidge } \\
\text { 1948, sub var. austro-africana) }\end{array}$ & $\begin{array}{l}20-26 \times 17.5-20 \mu \mathrm{m} \text { (in Latin description), } 22.5- \\
32 \times 17.5-25 \mu \mathrm{m} \text { (in English description), spore } \\
\text { wall } 1.5-2 \mu \mathrm{m} \text { thick, germ pores scattered, 5-6 }\end{array}$ & $\begin{array}{l}30-50 \times 22.5-35 \mu \mathrm{m} \text {, spore wall } 3-4 \mu \mathrm{m} \text { thick, at } \\
\text { apex } 5-6(8) \text {, pedicel persistent }\end{array}$ \\
\hline $\begin{array}{l}\text { P. austro-africana (from Laundon } \\
\text { 1963b, sub var. austro-africana) }\end{array}$ & $\begin{array}{l}22-25 \times 19-22 \mu \mathrm{m}(23.2 \times 20.8 \mu \mathrm{m}), \text { spore wall } \\
1.5-4 \mu \mathrm{m} \text { thick }\end{array}$ & Not specified \\
\hline $\begin{array}{l}\text { P. austro-africana South Africa } \\
\text { (RSA 96) }\end{array}$ & $\begin{array}{l}23-28 \times 20-23 \mu \mathrm{m}(25.4 \times 21.7 \mu \mathrm{m}), \text { spore wall } \\
1.5-2 \mu \mathrm{m} \text { thick, at germ pores } 3-4 \mu \mathrm{m} \text {, germ } \\
\text { pores scattered, } 6-8\end{array}$ & $\begin{array}{l}38-50 \times 26-32 \mu \mathrm{m}(43.3 \times 29.3 \mu \mathrm{m}) \text {, spore wall } \\
\text { ca. } 2 \mu \mathrm{m} \text { thick, at apex } 3.5-7 \mu \mathrm{m} \text {, pedicel frail }\end{array}$ \\
\hline $\begin{array}{l}\text { P. austro-africana South Africa } \\
\text { (RSA 156) }\end{array}$ & $\begin{array}{l}25-34 \times 17-22.5 \mu \mathrm{m}(28.3 \times 20.1 \mu \mathrm{m}) \text {, spore wall } \\
\text { ca. } 2 \mu \mathrm{m} \text { thick, at germ pores up to } 4 \mu \mathrm{m} \text {, germ } \\
\text { pores scattered, } 5-8\end{array}$ & $\begin{array}{l}37-45(47) \times 24-30 \mu \mathrm{m}(42.2 \times 27.3 \mu \mathrm{m}) \text {, spore } \\
\text { wall } 3-3.5 \mu \mathrm{m} \text { thick, at apex } 5-8 \mu \mathrm{m} \text {, pedicel } \\
\text { frail }\end{array}$ \\
\hline $\begin{array}{l}\text { P. austro-africana South Africa } \\
\text { (RSA 194) }\end{array}$ & $\begin{array}{l}24-28 \times 21-23 \mu \mathrm{m}(26.0 \times 21.8 \mu \mathrm{m}) \text {, spore wall ca. } \\
2-2.5 \mu \mathrm{m} \text { thick, at germ pores } 3.5-4.5 \mu \mathrm{m} \text {, germ } \\
\text { pores scattered, } 5-7\end{array}$ & Not present \\
\hline $\begin{array}{l}\text { P. austro-africana South Africa } \\
\text { (RSA 399) }\end{array}$ & $\begin{array}{l}24-30 \times 20.5-23.5 \mu \mathrm{m}(27.5 \times 22.0 \mu \mathrm{m}) \text {, spore wall } \\
\text { ca. } 2 \mu \mathrm{m} \text { thick, at germ pores } 5-6 \mu \mathrm{m} \text {, germ pores } \\
\text { scattered, } 5-7\end{array}$ & $\begin{array}{l}39-51 \times(22.5) 26-32 \mu \mathrm{m}(44.8 \times 28.7 \mu \mathrm{m}) \text {, spore } \\
\text { wall } 2.5-3.5 \mu \mathrm{m} \text { thick, at apex } 6-8 \mu \mathrm{m} \text {, pedicel } \\
\text { frail }\end{array}$ \\
\hline
\end{tabular}

germinationis inconspicuis 5-6 sparsis papillis latis humilibus praeditis. Telia abaxialia gregaria, mox nuda, rotundata, pulvinata, primum aurantiaco-brunnea deinde saturate ferruginea, textura carnosa vel semi-compacta; teliosporae post maturitatem germinantes, ellipsoideae ad subclavatae rariter late ellipsoideae, ad septum leniter constrictae, 44$70 \times 21-27(56.1 \times 23.9 \mu \mathrm{m})$, cellula distali ovoidea late ellipsoidea vel obpyriformi, cellula proximali late ellipsoidea subglobosa vel hilum versus attenuata, pariete levi pallide aurantiaco-brunneo ca. $1 \mu \mathrm{m}$ crasso in cellula proximali, $1-1.5 \mu \mathrm{m}$ in cellula distali, 4-6 $\mu \mathrm{m}$ in apice, usque ad $4 \mu \mathrm{m}$ in poro germinationis cellulae proximalis, poris germinationis in apice et septum juxta; mesosporae sparsae, 29-43×(17)20-24 $\mathrm{m}$; pedicello leniter incrassato stramineo vel pallide brunneo usque ad $55 \mu \mathrm{m}$ longo.

\section{In foliis Helichrysi sp. (Asteraceae)}

Aecia singly or in small groups on abaxial side of leaves, with white slenderly cylindrical peridium; aeciospores broadly ellipsoid to subglobose, often slightly deformed and subangular, 23-32×20-25 $\mu \mathrm{m}$ (mean $27.2 \times 22.5 \mu \mathrm{m}$ ), spore wall hyaline to subhyaline, ca. $2 \mu \mathrm{m}$ thick (incl. ornament), rather evenly and finely verrucose; inner side of peridial cells with irregular, dense, fine to moderately coarse warts, outer side essentially similar but warts flat and inconspicuous giving the surface an almost smooth to papillose appearance. Uredinia scattered, often singly, more rarely in small groups on abaxial side of leaves, dark brown, at the base blackish-brown, cupola-shaped with central aperture, provided with an overarching peridium composed of several layers of compressed, brown cells, spore mass cinnamon to ferrugineous; urediniospores subglobose to obovoidal, $23-28 \times 21-24 \mu \mathrm{m}$ (mean $25.4 \times$ $22.6 \mu \mathrm{m}$ ), spore wall ca. $1.5-2 \mu \mathrm{m}$ thick, inconspicuously bilaminate with a very thin exterior, subhyaline to strawcoloured layer and a thicker, pale and dull brown inner layer, evenly echinulate with rather fine spines about 2 $3 \mu \mathrm{m}$ apart, germ pores inconspicuous, 5-6, scattered, with broad, flat caps. Telia abaxial, in small groups, early naked, round, pulvinate, first orange-brown, later ferrugineous, soft to semi-compact; teliospores ellipsoid to subclavate, rarely broadly ellipsoid, slightly constricted at septum, 44$70 \times 21-27$ (mean $56.1 \times 23.9 \mu \mathrm{m}$ ), distal cell ovoid to broadly ellipsoid or obpyriform, proximal cell broadly ellipsoid, subglobose or almost wedge-shaped, tapering towards the hilum, spore wall smooth, light brown with orange tinge, ca. $1 \mu \mathrm{m}$ thick in proximal cell, $1-1.5 \mu \mathrm{m}$ in the distal one, thickening to $4-6 \mu \mathrm{m}$ at the apex and to $4 \mu \mathrm{m}$ at the germ pore of the proximal cell, germ pores 
Fig. 2 Puccinia naufraga (type). a Urediniospores in optical section. b Lateral part of uredinium showing peridial cells (stars) and the base of the cupola-like cover (arrow). c Teliospores and a single onecelled mesospore (star). d Teliospores. Arrows in c and d point to the teliospore apex which is less pigmented than the remaining spore wall and shows an inconspicuous lenticular swelling. Bars $=10 \mu \mathrm{m}$
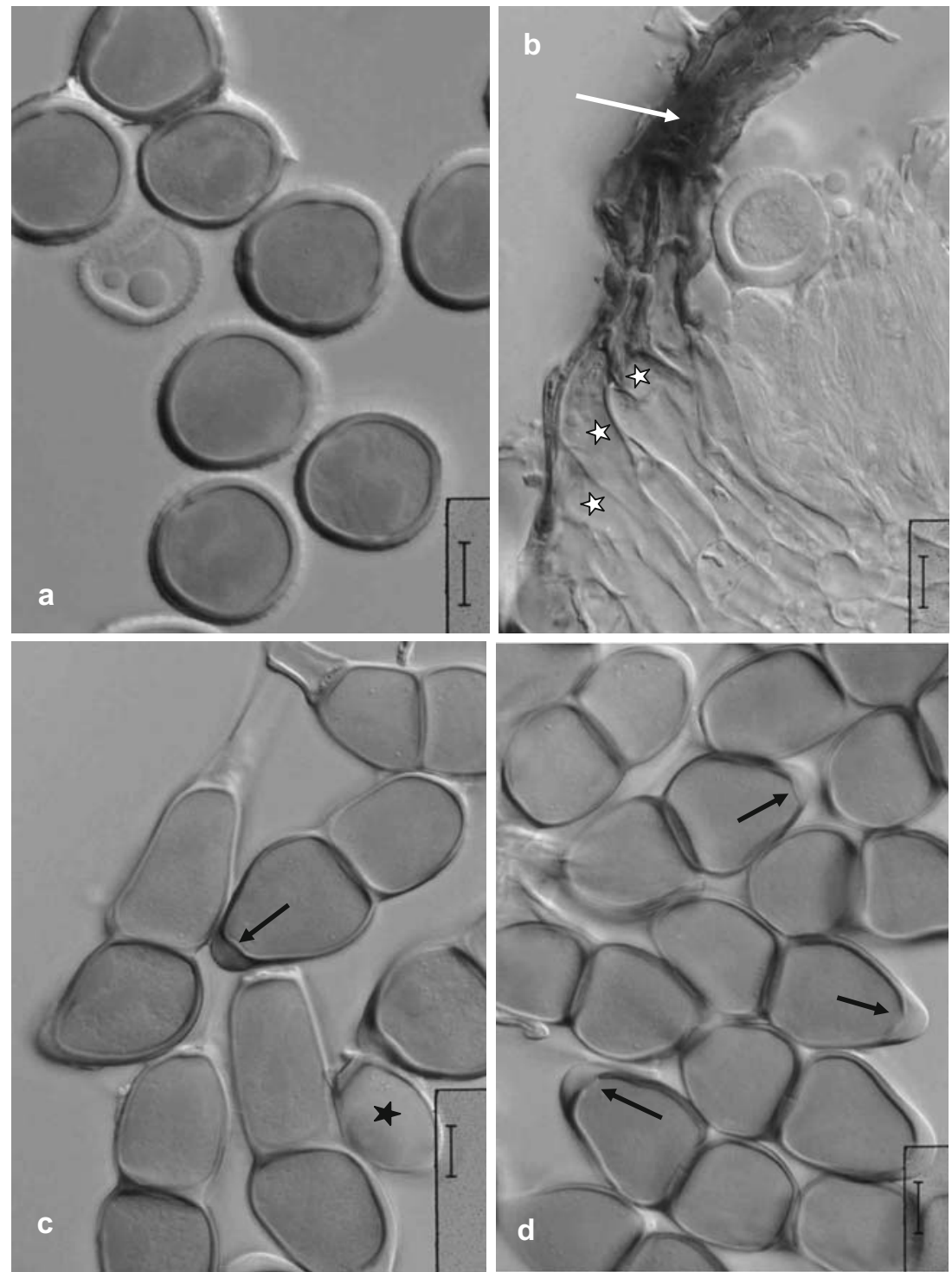

apical and adjacent to the septum, with a thickening that is less pigmented than the remaining wall and most often lenticular in the distal cell, germinating upon maturity; onecelled mesospores scattered, 29-43×(17)20-24 $\mu \mathrm{m}$, with pale brown, ca. $1 \mu \mathrm{m}$ thick wall, slightly thicker at apex; pedicel broadly attached, slightly thick-walled, strawcoloured to pallid brown, up to $55 \mu \mathrm{m}$ long.

On leaves of Helichrysum sp. (Asteraceae).

Holotype (PREM 60146): South Africa, Western Cape Prov., Cape Peninsula S of Simons' Town, 'Thomas Tucker Shipwreck Trail', 34 ${ }^{\circ} 15^{\prime} 56.3^{\prime \prime} \mathrm{S}, 18^{\circ} 23^{\prime} 04.5^{\prime \prime} \mathrm{E}$, alt. ca. $5 \mathrm{~m}$ a.s.l., on Helichrysum sp., leg. A. Rössel, E. Uhlmann and R. Berndt, 6 Nov 2005 (RSA 431, I/II/III).

$P$. naufraga differs from $P$. kalchbrenneri by less pigmented, orange-brown teliospore walls, a thinner teliospore apex and the apical germ pore with a small, lenticular papilla-like thickening (Figs. 2c-d, 4) which is less pigmented than the remaining wall. The thickening is visible until germination of the teliospores. Similar thickenings, though more pronounced, also occur in P. macowani but which differs by aeciospores with broad, flat warts and by the lack of a uredinial stage. In P. kalchbrenneri, the teliospore apex has a more or less pronounced conical pit in the spore wall probably indicating the location of the germ pore. It has not been proven so far that $P$. kalchbrenneri has an aecial stage though Doidge (1927) assumed that it may be represented by Aecidium helichrysi Doidge. Aeciospores of $P$. naufraga are hardly distinguishable from A. helichrysi but have slightly thinner spore walls which tend to be more finely verruculose.

Both $P$. naufraga and P. kalchbrenneri possess peridiate uredinia (Fig. 2b). The peridium first covers young uredinia like a cupola but later becomes evanescent. It is built up by one to several layers of compressed hyphae that become 
Fig. 3 Puccinia naufraga (type). a Aeciospores in optical section. b Aeciospores, focus on spore surface showing verruculose ornament. c Peridial cells, surface of inner tangential wall. d Peridial cells, surface of outer tangential wall. Bars $=20 \mu \mathrm{m}$
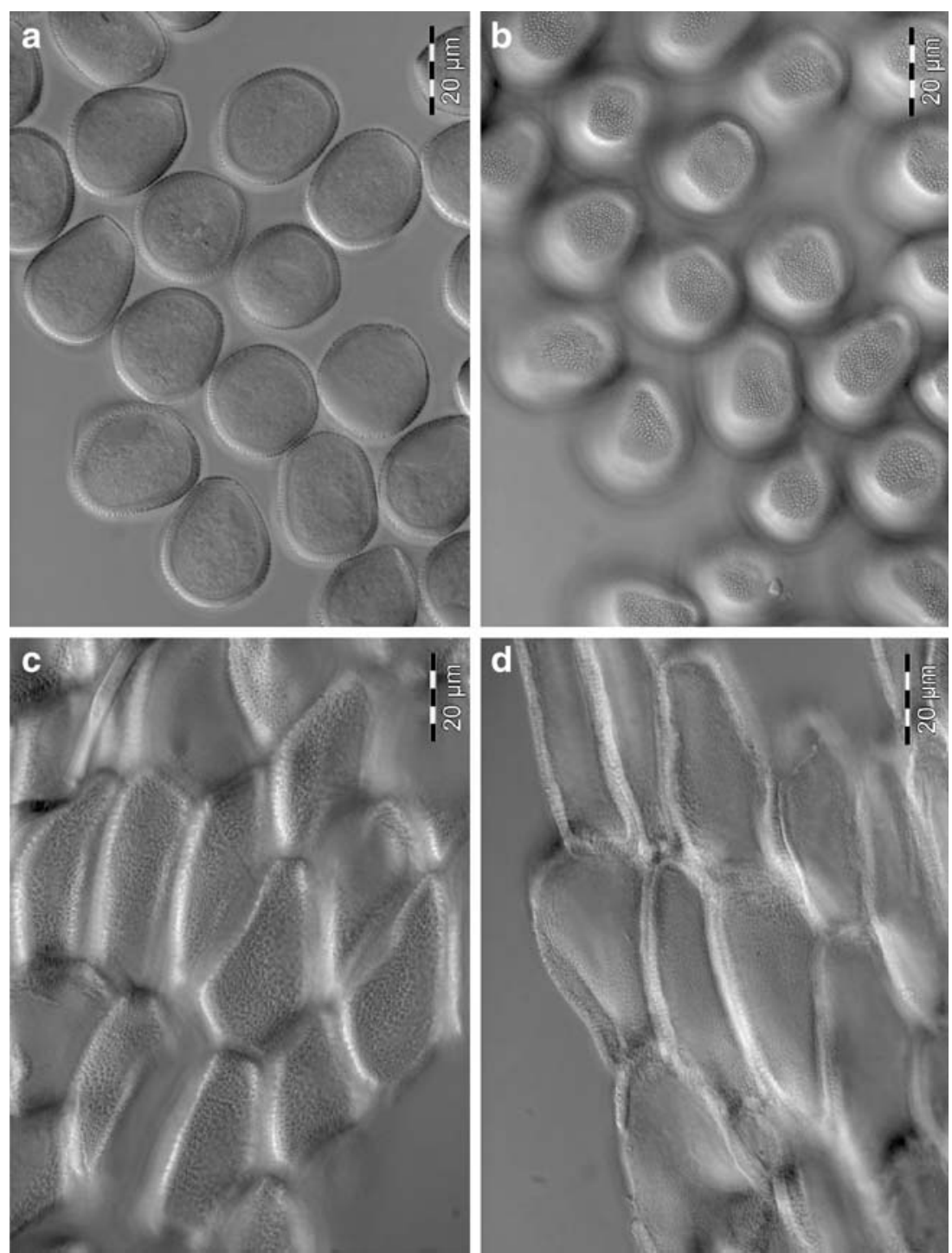

very indistinct towards the apex of the peridium which hence appears more or less amorphous in section and face view. The presence of the peridium results in a characteristic bullate to broadly flask-like shape of the uredinia which liberate the spores through an irregular pore or slit at their apex. Among Puccinia species on Helichrysum the presence of a uredinial peridium was first reported in $P$. cornurediata R. Berndt which is characterised by conspicuous horn-like peridia (uredinia of Uredostilbe-type). As discussed by Berndt and Uhlmann (2006), this character has been used to delimit the genus Miyagia from Puccinia. In young uredinia of $P$. kalchbrenneri and $P$. naufraga, the peridia resembled the similar if more delicate dome-shaped uredinial peridia of members of Pucciniastraceae, Cronartium and Melampsora (Moss 1926, 1928). Such uredinia have been assigned to the anamorph genus Milesia. It is evident that the occurrence of morphologically similar uredinia does not indicate a closer relationship between the discussed Puccinia species and members of the named taxa.

The following key comprises Puccinia species known from South Africa on Helichrysum species. It should be noted that it may be impossible to determine a specimen with only a single spore state.

1 Teliospores with very irregularly thickened, knotty or bulged cell wall, germ pores depressed 1/3-2/3 in both cells; uredinia unknown P. pienarii

$1^{*}$ Teliospores with other characters, germ pores apical and close to septum .. 2

2 Teliospores uniformly thin-walled, straw-coloured to ochraceous; aeciospores with flat, button-like warts; uredinia unknown P. horti-kirstenboschi

$2 *$ Teliospores with apically thickened wall, strawcoloured to chestnut brown 


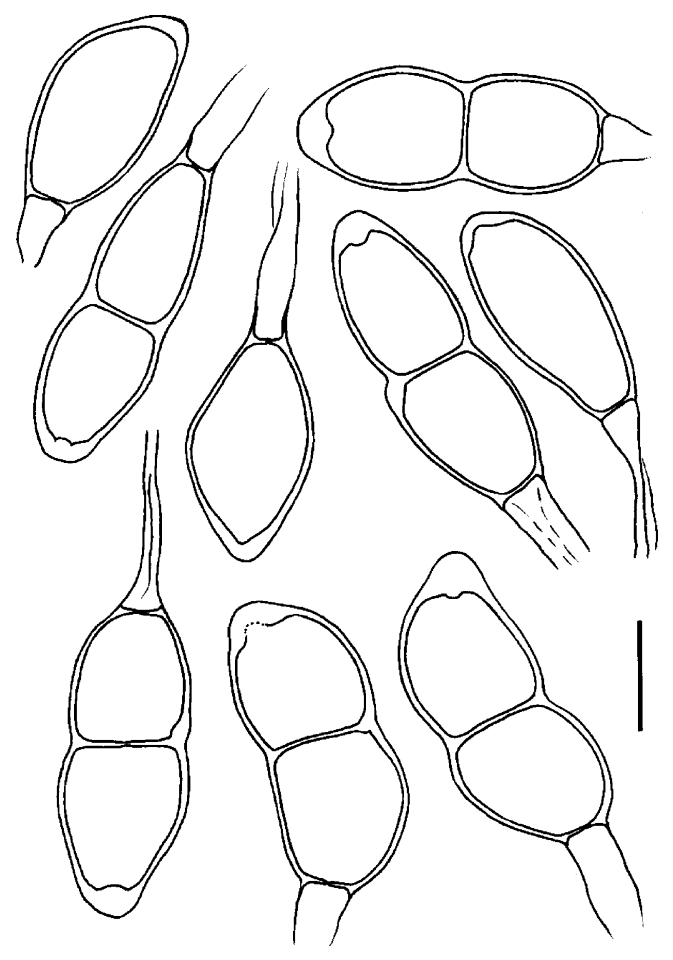

Fig. 4 Puccinia naufraga (type). Teliospores, among them three onecelled mesospores. Bar $=20 \mu \mathrm{m}$

3 Uredinia with a slenderly cylindrical to subconical peridium up to $1 \mathrm{~mm}$ long, composed of linear, golden, thick-walled hyphae P. cornurediata

3* Uredinia with bullate, cupola-like, delicate peridium, not peridiate (?), or uredinia unknown ....

4 Telia ferrugineous; teliospores light to orange brown, spore apex with a small to large lenticular to subgloboid pallid swelling, only rarely with a conical pit ................................................................... 5

5 teliospores ellipsoidal to fusiform, with a subglobose or broadly ellipsoidal thickening at germ pores; aeciospores with broad, flat, button-like warts; uredinia unknown . P. macowani

$5^{*}$ teliospores ellipsoidal, with orange brown wall and a small lenticular swelling at the spore apex; uredinia with cupulate peridium; aeciospores finely and densely verrucose P. naufraga

4* Telia apricot, ferrugineous or blackish brown; teliospores apically thickened, with or without conical pits at the germ pores but not with lenticular or subgloboid apical swelling

6 Telia apricot to ferrugineous, erumpent; teliospores fusiform to ellipsoidal with straw-coloured wall and an oblique thickening at the apex, often conspicuously thickened in the angles of the septum; uredinia unknown P. subindumentana

6* Telia dark brown to blackish brown, erumpent (to crustose); teliospore wall more deeply pigmented, apically thickened but generally not obliquely; uredinia known 7

7 Urediniospore wall 2-3 $\mu \mathrm{m}$ thick, yellow-brown; teliospores relatively broad $(21-37 \mu \mathrm{m})$; aecia unknown P. rocherpaniana

7* Urediniospore wall 1-2 $\mu \mathrm{m}$ thick, straw-coloured to light orange brown; teliospores narrower on average; aecial stage maybe present and is possibly identical with Aecidium helichrysi . P. kalchbrenneri (vars.)

Poaceae

Uromyces on Pentaschistis

Figure 5.

Material examined: South Africa, Western Cape Prov., Cederberge Mountains, Driehoek, on Pentaschistis pallida (Thunb.) Linder, leg. E. Uhlmann and R. Berndt, 12 Oct 2004 (RSA 5, II/III). South Africa, Western Cape Prov., Vanrhynsdorp, viewpoint above Vanrhynspass, $31^{\circ} 22^{\prime} 19.1^{\prime \prime} \mathrm{S}$, $19^{\circ} 01^{\prime} 02.3^{\prime \prime}$, alt. ca. $825 \mathrm{~m}$ a.s.1., on P. cf. pallida. leg. A. Rössel, E. Uhlmann and R. Berndt, 11 Oct 2005 (RSA 145, II/III). South Africa, Western Cape Prov., Vanrhynsdorp, parking bay at Vanrhynspass, on P. airoides Stapf, leg. A. Rössel, E. Uhlmann and R. Berndt, 11 Oct 2005 (RSA 168, II/III).

Gjærum (1988) described U. pentaschistidis on $P$. airoides from South Africa based on the telial state. We collected three specimens of Uromyces on P. airoides and $P$. pallida which revealed telio- and urediniospores. The teliospores from both host species were very similar but slightly smaller on P. airoides (Table 2). They agreed quite well with the description of $U$. pentaschistidis given by Gjærum though he described thicker spore walls (3-4 $\mu \mathrm{m}$ at sides vs ca. $2 \mu \mathrm{m}$, up to $8 \mu \mathrm{m}$ at the apex vs $4-7 \mu \mathrm{m}$ ). The urediniospores obtained from the present specimens were similar by their globose to broadly ellipsoid or broadly obovoid shape, by ca. $1.5-2 \mu \mathrm{m}$ thick walls which are evenly and rather densely echinulate by delicate spines, and by the presence of 9-14 scattered germ pores. The spores differed, however, among the three specimens with regard to their size and the wall thickening at the germ pores (Table 2). The urediniospores taken from $P$. airoides (RSA 168, Fig. 5a,b) were considerably smaller than those from P. pallida (Fig. 5c,d) and showed conspicuous thickenings at the germ pores. More material needs to be studied, however, to decide whether the observed differences are constant. Should it turn out that the rusts on P. pallida and $P$. airoides are different species it would be difficult to find out which one belongs to $U$. pentaschistidis. The teliospores are too similar in all specimens to allow a safe distinction. Urediniospores, however, which do seem to be 
Fig. 5 Uromyces pentaschistidis. a Urediniospores, focus on spore surface (RSA 168, on Pentaschistis airoides). b Urediniospores in optical section (RSA 168). Note internal swellings of spore wall at germ pores. c Urediniospores, focus on spore surface (RSA 145, on P. pallida). d Urediniospores in optical section (RSA 145). The spore wall is only slightly swollen at the germ pores. Bars $=20 \mu \mathrm{m}$
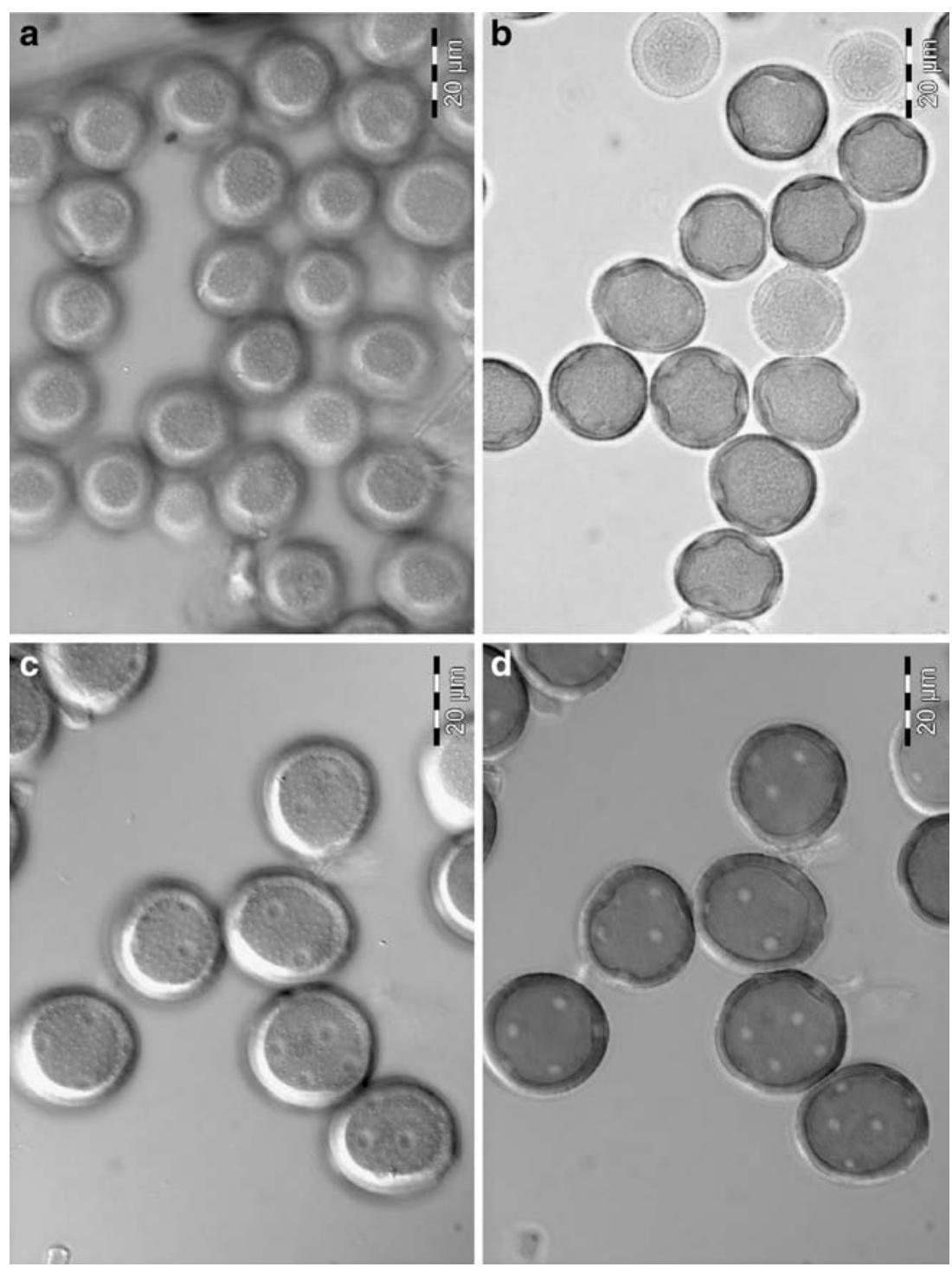

reasonably different are unknown in $U$. pentaschistidis. Unfortunately, type material of $U$. pentaschistidis could not be obtained and searched for the presence of urediniospores. Therefore, I provisionally assign all studied specimens to $U$. pentaschistidis.

\section{Rhamnaceae}

Uredo fynbosense R. Berndt, sp. nov.

Figure 6.

Etymology: Fynbos, habitat of the known hosts of the present species.

Spermogonia, aecia et telia absentia. Uredinia indumento lanoso coperta, solitaria vel laxe sparsa in pagina abaxiali foliorum, subepidermalia, minuta, pallide cinnamomea, pulverulenta, hyphis paucis paraphysiformibus tenue tunicatis praedita sed structuras proprias carentia quas soros circumdant; urediniosporae praecipue obovoideae, magis rariter ellipsoideae ad late ellipsoideae vel subclavatae, $19-28(31) \times 14-18 \mu \mathrm{m}(23.5 \times 16.1 \mu \mathrm{m})$, pariete pallide aureo ca. $1 \mu \mathrm{m}$ crasso non vel lenissime incrassato apicem versus, aequaliter et sate delicate echinulatae spinis inter se 1.5-2.5 $\mu \mathrm{m}$ distantibus, minus delicate et densiore echinulatae hilum versus, poris germinationis obscuris verosimiliter 2-3(4?) approx. aequatorialibus.

In foliis Phylicae specierum.

Spermogonia, aecia and telia not present. Uredinia singly or sparsely scattered on abaxial side of leaves, hidden under the woolly indument, subepidermal, tiny, pallid cinnamon brown, pulverulent, without clearly differentiated binding structures though a few thin-walled, hyaline, cylindrical paraphysis-like hyphae are sometimes present which do not appear to represent spore pedicels; urediniospores mostly obovoid, more rarely ellipsoid to broadly ellipsoid, subclavate, $19-28(31) \times 14-18 \mu \mathrm{m}$ (mean 
Table 2 Comparison between uredinio- and teliospores of Uromyces on Pentaschistis pallida and P. airoides

\begin{tabular}{lccc}
\hline Host (specimen) & Urediniospores (means) & Urediniospores, germ pores & Teliospores (means) \\
\hline On P. pallida (RSA 5) & $(25) 27-31.5 \times 22.5-26 \mu \mathrm{m}$ & $9-12$, scattered, spore wall & $21.5-28(30) \times 17-22 \mu \mathrm{m}$ \\
& $(30.2 \times 24.2 \mu \mathrm{m})$ & slightly thickened at pores & $(24.7 \times 20.0 \mu \mathrm{m})$ \\
On P. pallida (RSA 145) & $27-30 \times 24.5-28 \mu \mathrm{m}$ & $10-12$, scattered, spore wall & $21-27 \times(15) 17-23 \mu \mathrm{m}$ \\
& $(28.7 \times 26.4 \mu \mathrm{m})$ & slightly thickened at pores & $(24.2 \times 19.7 \mu \mathrm{m})$ \\
On P. airoides (RSA 168) & $21-25(27) \times 20.5-23 \mu \mathrm{m}$ & $11-14$, scattered, spore wall & $19-24 \times 16.5-21 \mu \mathrm{m}$ \\
& $(23.4 \times 21.6 \mu \mathrm{m})$ & conspicuously thickened at pores & $(21.4 \times 19.6 \mu \mathrm{m})$ \\
Uromyces pentaschistidis on & Unknown & & $(19) 22-24 \times 19-22 \mu \mathrm{m}$ \\
P. airoides (from Gjærum 1988) & & & (mean not calculated) \\
\hline
\end{tabular}

$23.5 \times 16.1 \mu \mathrm{m})$, spore wall pallid golden yellow, ca. $1 \mu \mathrm{m}$ thick, not or hardly thickened at apex, more or less evenly and rather finely echinulate with spines ca. 1.5-2.5 $\mu \mathrm{m}$ apart, somewhat more closely and less delicately echinulate towards the hilum, germ pores obscure, probably 2-3(4?), approximately equatorial.

On leaves of Phylica spp.

Holotype (PREM 60149): South Africa, Western Cape Prov., Vanrhynsdorp, ascent to Gifberg, $31^{\circ} 46^{\prime} 31.1^{\prime \prime} \mathrm{S}, 18^{\circ}$ 45'51.7"E, ca. $660 \mathrm{~m}$ a.s.1, on Phylica cf. oleifolia Vent., 12 Oct 2005, leg. A. Rössel, E. Uhlmann and R. Berndt (RSA 183, II). Isotype Z+ZT (ZT Myc 1270).

Additional material studied: South Africa, Western Cape Prov., Goukamma Nature Reserve SW of Groenvlei lake E of Lake Pleasant, $34^{\circ} 02^{\prime} 10.4^{\prime \prime} \mathrm{S}, 22^{\circ} 50^{\prime} 14.7^{\prime \prime} \mathrm{E}$, alt. ca. $20 \mathrm{~m}$ a.s.1., on Phylica cf. buxifolia L., 26 Oct 2005, leg. A. Rössel, E. Uhlmann and R. Berndt (RSA 372, II).

Phylica is a genus of about 150 species of which 134 occur in the Cape Floristic Kingdom, the vast majority of them endemic to the region (Linder 2003). The only rust fungus described from a member of this genus is Uredo phylicae Vienn.-Bourg. from the island of New Amsterdam.
According to the description given by Viennot-Bourgin (1970) it differs from the present species in much broader urediniospores $(25-31.5 \times 24-29 \mu \mathrm{m}$, mean $28 \times 26 \mu \mathrm{m})$ that are closely verruculose and have 5-7 germ pores. The affiliation of $U$. fynbosense with a telial genus is unknown but its general appearance indicates that it may be a member of Phakopsoraceae. Known Phakopsora species on Rhamnaceae are Ph. colubrinae Viégas and Ph. zizyphivulgaris Dietel, the latter with peridiate and paraphysate uredinia (Yen 1975), the former with unbounded uredinia and urediniospores similar to the present species (Viégas 1960).

\section{Rubiaceae}

Puccinia species on members of Rubioideae, tribes Rubieae and Anthospermeae

Findings of rust fungi on Galium species (Rubieae) from Western Cape Province revealed the widespread P. punctata Link and a similar, yet different Puccinia species which is described as P. montis-venenosi.
Fig. 6 Uredo fynbosense (holotype). a Urediniospores in optical section. b Urediniospores, focus on spore surface. Bars $=20 \mu \mathrm{m}$
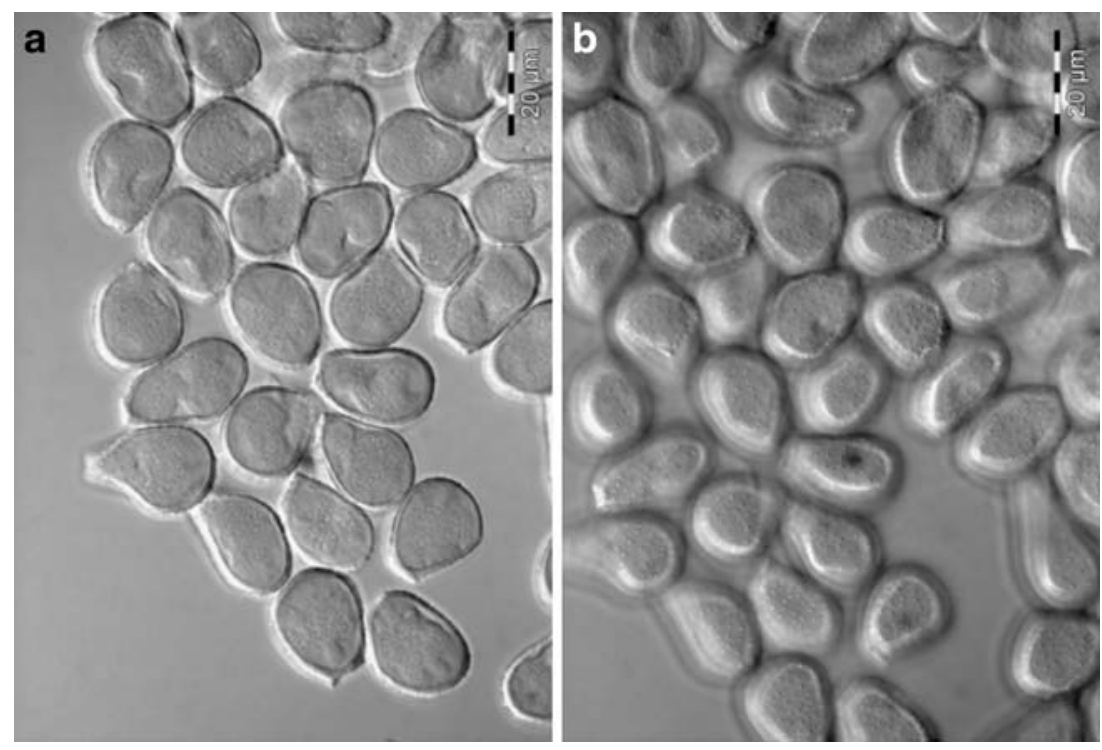
Puccinia montis-venenosi R. Berndt, sp. nov.

(Fig. 7)

Etymology: after the 'Gifberg' (= poison mountain), collection site of the type.

Spermogonia et aecia ignota. Uredinia praecipue in pagina foliorum abaxiali vel caulincola, subepidermalia, ferruginea, pulverulenta, telios evolvere possunt; urediniosporae late obovoideae late ellipsoideae, subglobosae, rariter late ovoideae vel globosae, 24-35×21-26 $\mu \mathrm{m}$ $(29.2 \times 23.2 \mu \mathrm{m})$, pariete aurantio-brunneo ca. $1.5(2) \mu \mathrm{m}$ crasso leniter incrassato (usque ad $3 \mu \mathrm{m}$ ) hilum versus sate delicate echinulato spinis ca. 1.8-3.2 $\mu \mathrm{m}$ inter se distantibus evanescentibus in dimidio inferiore sporarum in quarta vel quinta parte inferiore carentibus, poris germinationis 2 3 plusminusve aequatorialibus et aequidistantibus, papillis parvis et inconspicuis praeditis. Telia nigrescentia, subcompacta, pulvinata, rotundata vel elongata in caulibus; teliosporae clavatae, ellipsoideae, oblongae vel subfusi- formes, (32)36-70×16-27 $\mu \mathrm{m}(52.9 \times 21.1 \mu \mathrm{m})$, non vel paulum constrictae in septo, apice rotundato conico vel rariore - subtruncato rostellato vel irregulariter deformato, cellula proximali attenuata hilum versus, pariete levi sate aureo ad dilute castaneo (praecipue apicem versus) lateraliter ca. $2 \mu \mathrm{m}$ crasso in cellula proximali, $2-3 \mu \mathrm{m}$ in cellula distali, in apice 10-20 $\mu \mathrm{m}$ crasso, poris germinationis apicalibus et juxta septum, papillis carentibus, pedicello ad hilum late affixo $(7-10 \mu \mathrm{m})$ tenue tunicato dilute brunneo vel subhyalino fragili sed longitudinem usque ad $70 \mu \mathrm{m}$ attingenti.

In foliis caulibusque Galii specierum.

Spermogonia and aecia unknown. Uredinia predominantly on abaxial side of leaves or on stems, subepidermal, ferrugineous, pulverulent, may give rise to telia; urediniospores broadly obovoid, broadly ellipsoid, subglobose, rarely broadly ovoid or globose, $24-35 \times 21-26 \mu \mathrm{m}$ (mean $29.2 \times 23.2 \mu \mathrm{m})$, spore wall orange brown, ca. $1.5(2) \mu \mathrm{m}$ thick, slightly thicker (up to $3 \mu \mathrm{m}$ ) towards hilum, rather
Fig. 7 Puccinia montisvenenosi (paratype). a,b Teliospores showing a part of the variation with regard to teliospore size, shape and thickness of the spore apex. c Urediniospores in optical section. Note smooth spore base (arrows). d Urediniospores, focus on spore surface. Note smooth spore base (arrows) Bars $=50 \mu \mathrm{m}$ (a), $20 \mu \mathrm{m}(\mathbf{b}-\mathbf{d})$
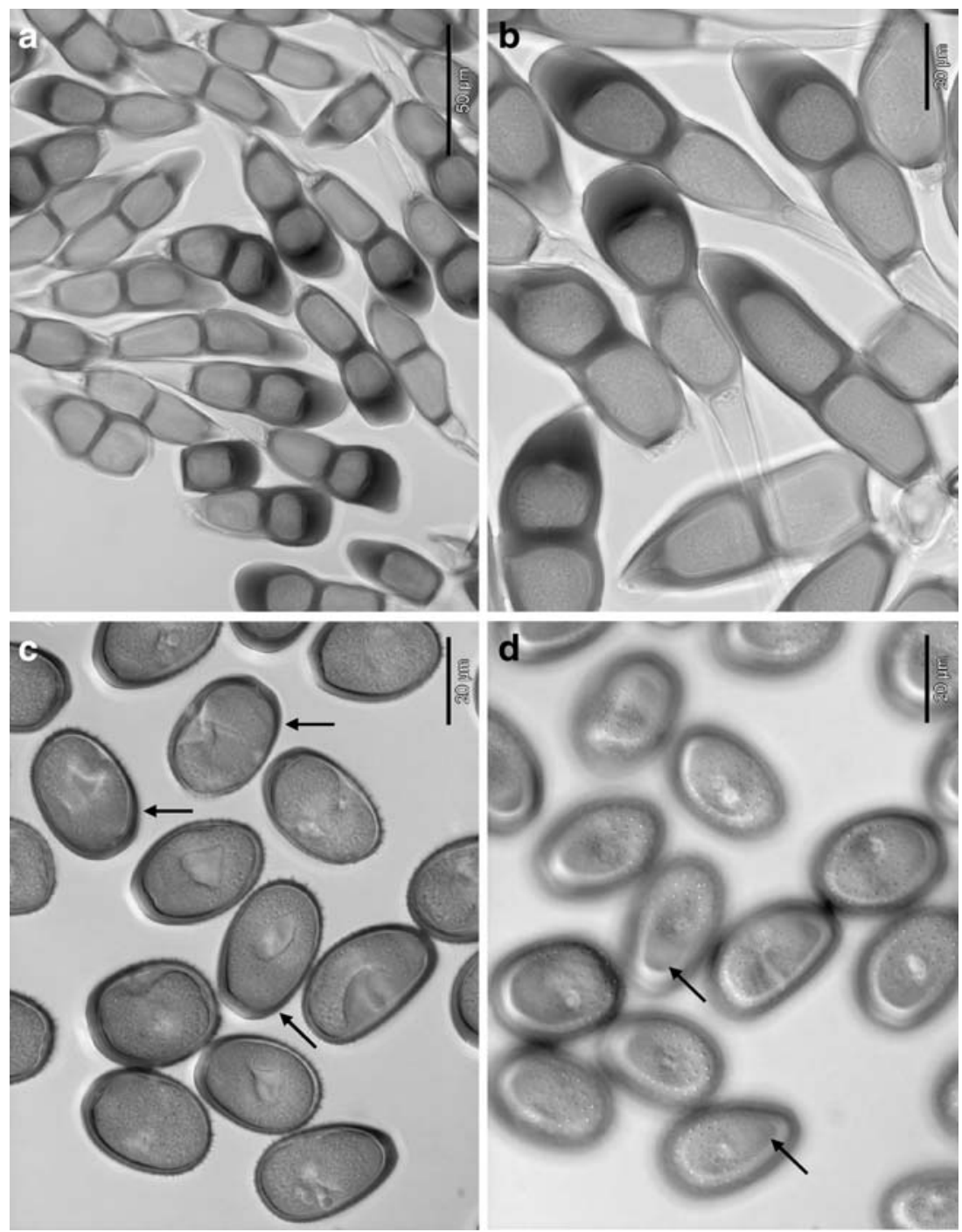
finely echinulate with spines ca. 1.8-3.2 $\mu \mathrm{m}$ apart, spines become smaller on proximal half of spores whilst proximal fourth or fifth is smooth, germ pores $2-3$, more or less equatorial and equidistant, with very small and inconspicuous caps. Telia blackish, subcompact, pulvinate and rounded, generally elongated on stems; teliospores clavate, ellipsoid, oblong or subfusiform, (32)36-70×16-27 $\mu \mathrm{m}$ (mean $52.9 \times 21.1 \mu \mathrm{m}$ ), not or hardly constricted at septum, apex rounded, conical, more rarely subtruncate, beaked or irregularly deformed, proximal cell tapering towards the hilum, spore wall smooth, deeply golden brown to light chestnut brown (especially in thickened apex), laterally about $2 \mu \mathrm{m}$ thick in proximal cell, $2-3 \mu \mathrm{m}$ in distal cell, apex 10-20 $\mu \mathrm{m}$ thick, germ pores apical and at septum, without papillae, pedicels up to $70 \mu \mathrm{m}$ long or breaking off shorter, collapsing or not, broadly attached $(7-10 \mu \mathrm{m})$ to spore base, more or less thin-walled, pale brownish or subhyaline.

On leaves and stems of Galium spp.

Holotype (PREM 60147): South Africa, Western Cape Prov., Vanrhynsdorp, gravel road to Gifberg/Matzikamma Mountains. SSE of Vanrhynsdorp, ascent to Gifberg, on Galium cf. spurium L. ssp. africanum Verdc., leg. A. Rössel, E. Uhlmann and R. Berndt, 12 Oct 2005 (RSA 178, II/III). Isotype Z+ZT (ZT Myc 1268). Paratype: South Africa, Western Cape Prov., Vanrhynsdorp, at Vanrhynspass, slopes at parking bay in middle section of pass road, on Galium cf. tomentosum Thunb. (non-flowering plant), leg. A. Rössel, E. Uhlmann and R. Berndt, 11 Oct 2005 (RSA 170, II/III).

Additional material examined: Puccinia punctata: South Africa, Western Cape Prov., Ceres, ascent to Gydopass, on two collections of Galium capense Thunb. cf. ssp. capense in Fynbos and roadside vegetation, leg. A. Rössel, E. Uhlmann and R. Berndt, 18 Oct 2005 (RSA 249 and 251, each II/III).

Puccinia montis-venenosi resembles $P$. punctata by the appearance of the uredinia and the telia and by similar uredinio- and teliospores. It differs essentially by the echinulation of the urediniospores which becomes finer towards the base of the spores and vanishes entirely on the proximal fourth or fifth of the spore surface (Fig. 7c, d). In $P$. punctata, the urediniospores are evenly echinulate. It should be noted that Klebahn (1914) observed partially smooth urediniospores, too, in specimens tentatively assigned to P. deminuta Vleugel on Galium uliginosum L. and $G$. palustre L. The smooth patches occurred mainly lateral on the spores, however, and did not comprise their proximal parts. Gäumann (1959) considered $P$. deminuta to be a forma specialis of $P$. punctata.

The investigated specimens were collected on two species of Galium and differed considerably from each other with regard to teliospore size. In the specimen from
Vanrhynspass, teliospores measured 48-70×19-27 $\mu \mathrm{m}$ (mean $57.2 \times 22.7 \mu \mathrm{m}$ ), in that from Gifberg (32)36-60× 16-22(24) $\mu \mathrm{m}$ (mean $48.8 \times 19.7 \mu \mathrm{m}$ ); the respective urediniospores measured $26-35 \times 21-24 \mu \mathrm{m}$ (mean $30.6 \times$ $22.4 \mu \mathrm{m}$ ) and $24-31(33) \times 22-26 \mu \mathrm{m}$ (mean $27.8 \times$ $24.0 \mu \mathrm{m})$. It may be interesting that $P$. punctata also has uredinio- and teliospores of rather variable size (Gäumann 1959).

Puccinia punctata from Gydopass revealed uredinia and telia. Urediniospores measured $22-28 \times 19-24 \mu \mathrm{m}$ (mean $24.5 \times 21.3 \mu \mathrm{m})$, the teliospores $(38) 40-60 \times 18-25 \mu \mathrm{m}$ (mean $47.8 \times 20.5 \mu \mathrm{m}$ ). The spore size and other characters tally well with descriptions of $P$. punctata by various authors (e.g. Gäumann 1959; Klebahn 1914). P. punctata is known from many different Galium species (Gäumann 1959) and has in addition been reported on members of Asperula, Rubia and Relbunium. The rust is autoecious but shows plasticity with regard to its life cycle with macrocyclic and demicyclic variants (Wurth 1905; Gäumann 1959). In South Africa, it was listed by Doidge $(1927,1950)$ on $G$. capense, with spermogonia, aecia and uredinia present. Only uredinia and telia are known so far for P. montisvenenosi and it is uncertain at this stage whether it is macrocyclic.

\section{Puccinia anthospermi Syd.}

Figure 8.

Material examined: South Africa, Western Cape Prov., Elim, Geelkop Hills, 34³3'46.7"S, $19^{\circ} 47^{\prime} 41.7^{\prime \prime} \mathrm{E}$, on Anthospermum galioides Rchb. f. ssp. galioides, leg. A. Rössel, E. Uhlmann and R. Berndt, 29 Oct 2005 (RSA 392, III).

Puccinia galopinae Cooke: South Africa, KwaZuluNatal, Inanda, on Galopina aspera Sond., leg. GM Wood (no. 602), Jun 1881 (PREM 11192 and 10474, types, each with III).

Two Puccinia species are known on southern African Anthospermeae: P. anthospermi on Anthospermum species and $P$. galopinae on Galopina species. In the original description of $P$. anthospermi on A. hirtum Cruse from South Africa, Sydow and Sydow (1904) described the teliospores as 35-46×16-21 $\mu \mathrm{m}$ large, apically thickened to $9 \mu \mathrm{m}$, with a pedicel up to $30 \mu \mathrm{m}$ long. Holm (1973) measured $40-50 \times 12-15 \mu \mathrm{m}$ for the teliospores, an apical thickening of up to $10 \mu \mathrm{m}$ and pedicels up to $40 \mu \mathrm{m}$ long on A. muricatum from Tanzania [this name does not occur in 'The International Plant Names Index' (2004) or Puff (1986). In 'World check list of Rubiaceae' (Govaerts et al. n.d.), A. muriculatum Hochst. ex A. Rich. (= A. herbaceum L. f.) is listed which may be meant]. He re-studied the "very poor" type collection and could not find essential differences between the specimens. 
Fig. 8 Puccinia anthospermi, teliospores (RSA 392). Arrow shows a single, three-celled spore. Stars indicate germinated teliospore cells Bars $=20 \mu \mathrm{m}$

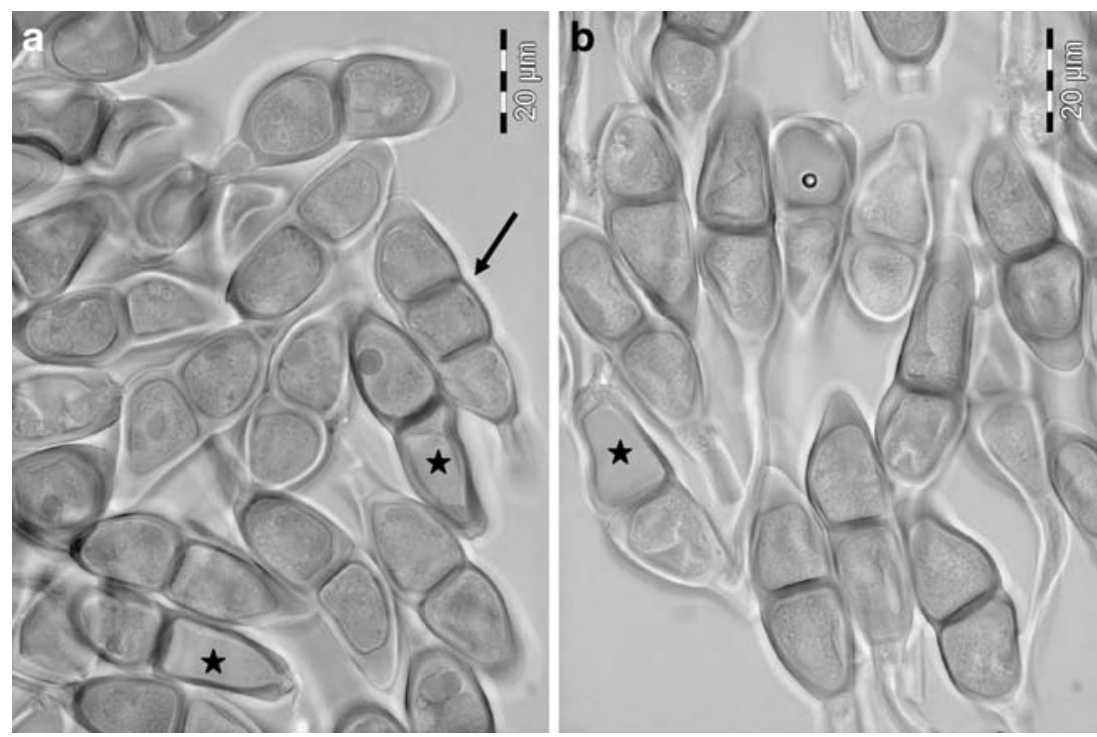

As the available descriptions of $P$. anthospermi are short, a more detailed one is provided based on the specimen on A. galioides ssp. galioides:

Telia abaxial on leaves, subepidermal, pallid to dark ferrugineous, strongly pulvinate, compact, discrete or confluent, up to $2 \mathrm{~mm}$ diam., with a white or greyish cast after germination of basidia; teliospores $38-55 \times 14$ $18.5 \mu \mathrm{m}$ (mean $46.8 \times 16.4 \mu \mathrm{m}$ ), ellipsoid, more rarely fusiform or oblong, two-celled (very rarely three-celled), at septum not or hardly constricted, apex conical, narrowly conical, more rarely rounded, proximal cell tapering towards the pedicel, spore wall smooth, pale golden brown to straw-coloured, ca. 1-2 $\mu \mathrm{m}$ thick at sides, 4-9 $\mu \mathrm{m}$ at spore apex which is slightly paler than the remaining wall, germ pores apical in distal cell, close to septum in proximal cell, spores germinate upon maturity, pedicels subhyaline, slightly thick-walled, up to $80 \mu \mathrm{m}$ long.

A very similar species is $P$. galopinae whose teliospores are described by Doidge (1927) to be 35-50×11-15 $\mu \mathrm{m}$, apex thickened to $7 \mu \mathrm{m}$ and with pedicels up to $70 \mu \mathrm{m}$ long. I measured (36)40-60×12.5-18 $\mu \mathrm{m}$ (mean 51.1× $15.0 \mu \mathrm{m}$ ), an apical thickening of 5-9 $\mu \mathrm{m}$ and pedicels up to $50 \mu \mathrm{m}$ long. Apart from slightly narrower and longer teliospores there is little to differentiate $P$. galopinae from $P$. anthospermi. Given this similarity and the close relationship of the host genera, one might assume that these rusts are conspecific. In this case, the older name $P$. galopinae would take precedence over P. anthospermi. $P$. anthospermi is known from South Africa and Tanzania (Holm 1973), P. galopinae from South Africa (Doidge 1950) and Nigeria (Eboh 1984). Eboh (1984) reported the rust on Victeria sp. This name does not seem to exist and is most probably an error for Virectaria Afzel. ex Sm. em. Bremek. which belongs to tribe Sabiceeae of subfam. Ixoroideae (Khan et al. 2008).
Solanaceae

Puccinia lycii Kalchbr. var. bizonata R. Berndt, var. nov.

Figure 9.

$\mathrm{Ab}$ varietate typica Pucciniae lycii differt urediniosporis brevioribus latioribus poris germinationis bizonate positis.

In foliis Lycii sp.

Uredinia almost entirely replaced by telia; urediniospores ferrugineous, ellipsoid, more rarely broadly ellipsoid, narrowly obovoid or almost oblong, 37-53× 21-24 $\mu \mathrm{m}$ (mean $43.6 \times 22.3 \mu \mathrm{m}$ ), spore wall ochraceous, ca. $1.5 \mu \mathrm{m}$ thick, apically to $2 \mu \mathrm{m}$, echinulate by spines ca.

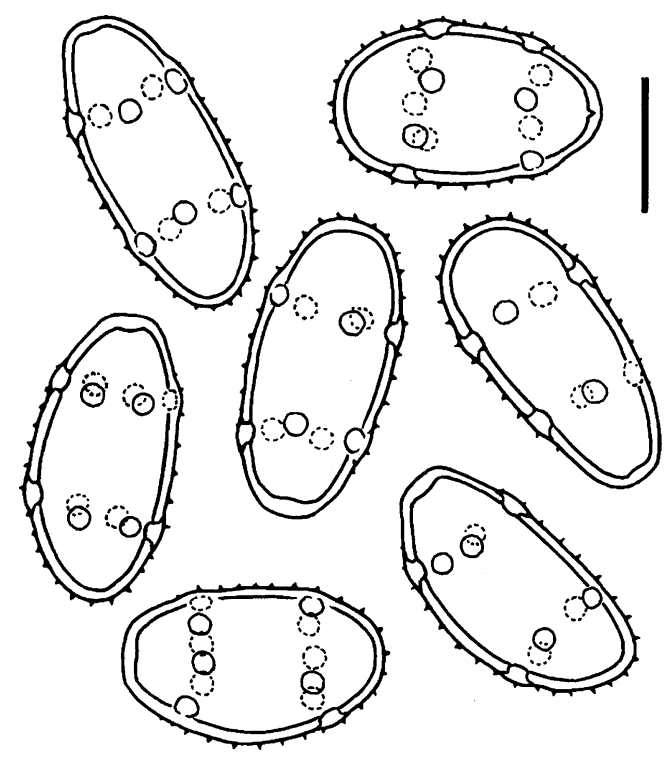

Fig. 9 Puccinia lycii var. bizonata (holotype). Urediniospores with bizonate germ pores. Bar $=20 \mu \mathrm{m}$ 
2-3.5 $\mu \mathrm{m}$ apart, becoming smooth in proximal fifth of spore surface, germ pores bizonate, rings each with 4-6(7) pores, rarely pores almost scattered, with small, flat subhyaline caps and slight internal thickening of the wall. Telia amphigenous on leaves, black, pulvinate and pulverulent; teliospores broadly ellipsoid, more rarely ellipsoid or obovoid, rounded at apex and towards hilum, sometimes tapering towards hilum, not or hardly constricted at septum, 39-52 $\times 24-30 \mu \mathrm{m}$ (mean $44.3 \times 26.0 \mu \mathrm{m}$ ), spore wall light chestnut brown, densely covered by fine or slightly coarser, flat or hemispherical warts, ca. $1.5-2.5 \mu \mathrm{m}$ thick, apically hardly thickened, germ pore of distal cell ca. 1/3 (-1/2) shifted towards septum, in the proximal cell ca. $1 / 2(-2 / 3)$ towards hilum, with broad, flat, yellowish brown caps, pedicel thick-walled, subhyaline, yellowish brown close to hilum, swelling strongly ca. $18-30 \mu \mathrm{m}$ from hilum to assume a more or less tuberous shape.

On the leaves of Lycium sp.

Holotype (PREM 60148). South Africa, Western Cape Prov., Nieuwoudtville, gravel road to Louriesfontein, trails at 'Windmill Museum', $31^{\circ} 19^{\prime} 10.5^{\prime \prime} \mathrm{S}, 19^{\circ} 07^{\prime} 03.0^{\prime} \mathrm{E}$, alt. ca. $670 \mathrm{~m}$ a.s.l., on non-flowering Lycium sp., leg. A. Rössel, E. Uhlmann and R. Berndt, 11 Oct 2005 (RSA 137). Isotype Z+ZT (ZT Myc 1269).

In $P$. lycii var. lycii, the vast majority of the urediniospores has (sub)equatorial germ pores. The new variety differs from the nominal one by shorter and broader urediniospores whose germ pores are constantly bizonate and generally more numerous within a ring. I would not have hesitated to describe it as a new species had not a study of the type of $P$. lycii var. lycii also revealed a few urediniospores with bizonate pores (Berndt and Uhlmann 2006). As it cannot be ruled out at present that $P$. lycii is variable with regard to the position of the germ pores only variety rank is conferred to the form with bizonate pores. For a key of African species of Puccinia on Lycium see Berndt and Uhlmann (2006).

\section{Zygophyllaceae (Zygophylloideae)}

Mennicken et al. (2005) surveyed rust fungi on African Zygophylloideae and distinguished four species of Uromyces on Zygophyllum. We found an additional Uromyces species that is described as $U$. eclipsis.

\section{Uromyces eclipsis R. Berndt \& A. R. Wood, sp. nov.}

\section{Figure 10.}

Etymology: Designating the appearance of the teliospores.

Spermogonia et uredinia non visa. Aecia aggregata vel singularia amphigena in foliis ramulorum scoparie deformium vel non deformium, inaperta cum peridio anguste conico, aperta cum peridio cylindrico ad anguste cyathiformi eburneo ca. $0.4-0.7 \mathrm{~mm}$ longo, margine integro vel sublacerato, cellulae peridii intus verrucis sate delicatis ad grossis confluentibus obsitae, extus conspicue striatae striis delicatis densis longitudinalibus subundulatis; aeciosporae subglobosae ad late ellipsoideae plerumque subangulosae, $25-31 \times 22-26.5 \mu \mathrm{m}(28.0 \times 24.0 \mu \mathrm{m})$, pariete hyalino ca. $1-1.5 \mu \mathrm{m}$ crasso dense delicateque verruculoso. Telia in foliis sparsa et amphigena subepidermalia atro-brunnea vel atra pulverulentia aeciis saepe consociata; teliosporae ovoideae late ellipsoideae vel subglobosae saepe leniter asymmetricae, 37-47 $\times 32$ $41 \mu \mathrm{m}$ (pro holotypo $40.0 \times 35.7 \mu \mathrm{m}$, pro paratypo $41.5 \times$ $37.0 \mu \mathrm{m}$ ), pariete distincte bilaminato, lamina interiore castanea ca. (3) $4-7 \mu \mathrm{m}$ crassa aequaliter remoteque echinulata spinis grossis ca. 3-5 $\mu \mathrm{m}$ longis et inter se 5$8 \mu \mathrm{m}$ distantibus, lamina exteriore straminea vel ochracea ca. 1.5-2.5(4) $\mu \mathrm{m}$ crassa, poro germinationis apicali vel subapicali papilla indistincta praedito vel sine illa, pedicello fragili brevi.

\section{In Zygophylli morgsanae L.}

Spermogonia and uredinia not seen. Aecia amphigenous and densely aggregated on leaves of witches' brooms or scattered and amphigenous on leaves of apparently unaltered branches, sometimes on small, weakly hypertrophied areas of leaves, closed with narrowly conical peridia, opened peridia cylindrical to narrowly cup-shaped, ca. 0.4 $0.7 \mathrm{~mm}$ long, with margin entire or weakly lacerated, ivory coloured; peridial cells verrucose on inner side with rather delicate to coarse warts which become confluent, on the outside with a conspicuous pattern of fine, longitudinal, often somewhat wavy, densely arranged, shorter or longer striae; aeciospores subglobose to broadly ellipsoid, generally subpolyhedral or slightly deformed by mutual pressure, 25-31 ×22-26.5 $\mu \mathrm{m}$ (mean $28.0 \times 24.0 \mu \mathrm{m})$, spore wall hyaline, ca. $1-1.5 \mu \mathrm{m}$ thick (incl. ornament), finely and densely verruculose, with some coarser warts interspersed. Telia scattered and amphigenous on leaves, subepidermal, blackish brown to black, pulverulent, often closely associated with aecia; teliospores ovoid, broadly ellipsoid or subglobose, often slightly asymmetrical, 37-47×32-41 $\mu \mathrm{m}$ (mean for holotype $40.0 \times 35.7 \mu \mathrm{m}$, for paratype $41.5 \times$ $37.0 \mu \mathrm{m}$ ), spore wall distinctly two-layered, with an inner, chestnut brown layer ca. (3) $4-7 \mu \mathrm{m}$ thick and a strawcoloured to ochraceous outer layer ca. 1.5-2.5(4) $\mu \mathrm{m}$ thick, inner wall layer evenly and distantly covered by coarse spines ca. 3-5 $\mu \mathrm{m}$ long and 5-8 $\mu \mathrm{m}$ apart, germ pore apical or subapical, visible as a conical or trapezoid pit, sometimes indistinct, sometimes with an ill-defined and inconspicuous papilla, pedicels frail, normally breaking close to the hilum.

On Zygophyllum morgsana L.

Holotype (ZT Myc 643): South Africa, Western Cape Prov., Plettenberg Bay, Keurboomstrand, on Z. morgsana, leg. H. Schuepp, 22 Oct 1959 (sub U. trollipi, I [obsolete] /III). 
Fig. 10 Uromyces eclipsis. a

Teliospores (holotype). b Aeciospores in optical section (RSA 378). c Aeciospores, focus on spore surface (RSA 378). d Peridial cells, inner tangential wall with moderately coarse warts (RSA 378). e Peridial cells, outer tangential wall with finely striated surface (RSA 378). Bars $=10 \mu \mathrm{m}$
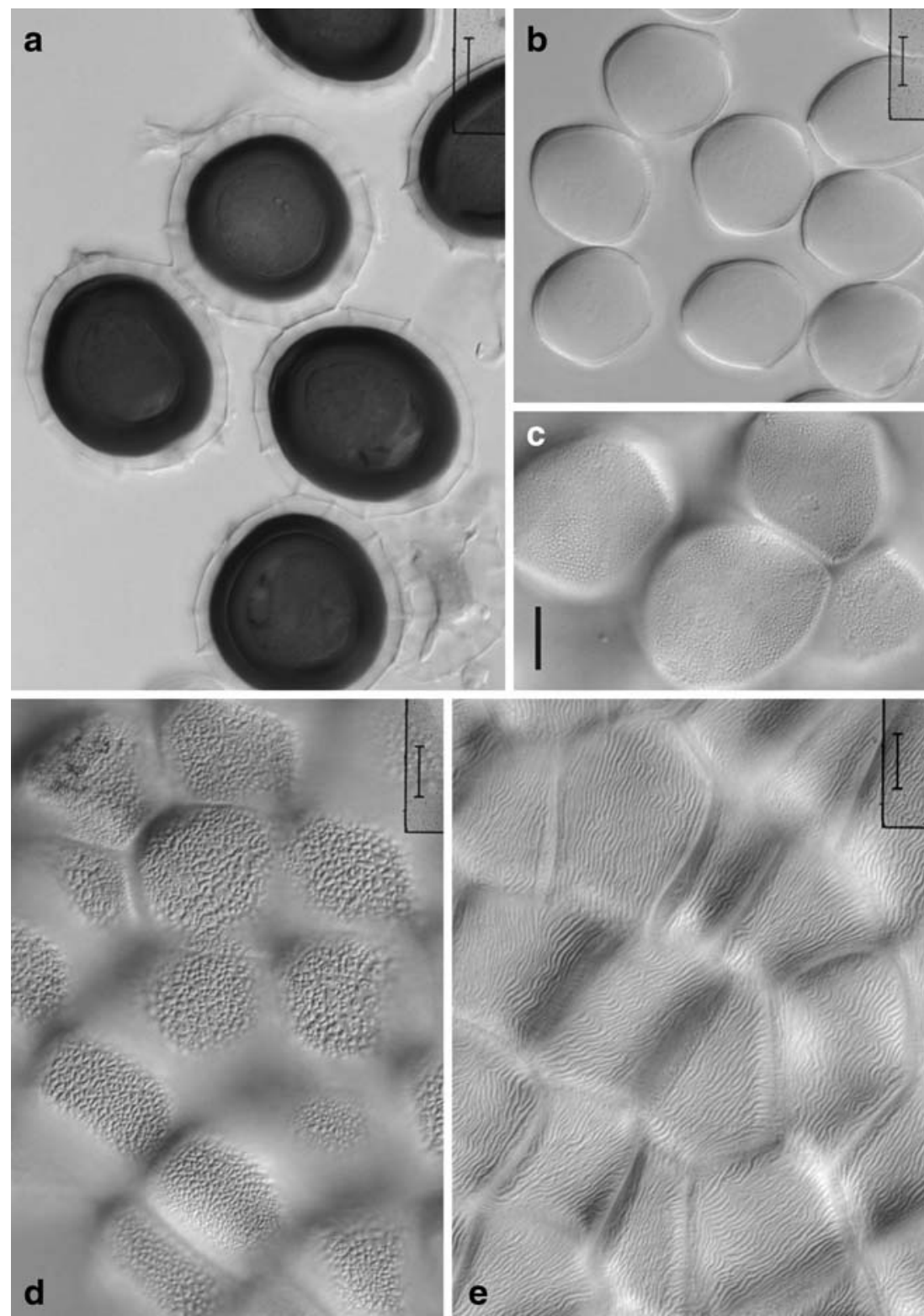

Paratype (PREM 60150): South Africa, Western Cape Prov., Groenvlei E of Lake Pleasant, at Goukamma Nature Reserve, scrub along 'Groenvlei trail' at southern side of Groenvlei, $34^{\circ} 02^{\prime} 01.3^{\prime \prime} \mathrm{S}, 22^{\circ} 51^{\prime} 38.1^{\prime \prime} \mathrm{E}$, alt. ca. $16 \mathrm{~m}$ a.s.l., on Z. morgsana, leg. A. Rössel, E. Uhlmann and R. Berndt, 26 Oct 2005 (RSA 378, I/III)

Additional material studied by A.R. Wood: South Africa, Western Cape Prov., Koppie Alleen, De Hoop Nature

Table 3 Comparison between uredinio- and teliospores of Uredo zygophylli Jacz. (= U. zygophyllina Sacc.), U. zygophylli Henn. and Uromyces dinteri Mennicken, Maier \& Oberw

\begin{tabular}{lcc}
\hline Species (specimen) & Urediniospores (means) & Teliospores (means) \\
\hline U. zygophylli Jacz. = U. zygophyllina & $25-31 \times 22-27 \mu \mathrm{m}(28.8 \times 24.4 \mu \mathrm{m})$, germ pores 5-8, & $27-36 \times 27-33 \mu \mathrm{m}(31.5 \times 29.2 \mu \mathrm{m})$, excl. \\
Sacc. (ZT Myc 644) & most often 6, with caps (own observations). & outer wall layer (own measurements) \\
& $24-36 \times 20-27 \mu \mathrm{m}($ Mennicken et al. 2005) & \\
U. zygophylli Henn. (holotype, B) & $30-36 \times 24-29 \mu \mathrm{m}(31.0 \times 25.8 \mu \mathrm{m})$, germ pores 6-8, & Only three teliospores encountered \\
& most often 6, with caps (own observations) & \\
Urom. dinteri Mennicken, Maier \& & $31-40(42) \times(22) 24-36 \mu \mathrm{m}$, germ pores 6-9, & $(31) 34-44 \times 30-42 \mu \mathrm{m}$, excl. outer wall \\
Oberw. & without caps $($ Mennicken et al. 2005) & layer (Mennicken et al. 2005)
\end{tabular}


Reserve, E of Bredasdorp, $34^{\circ} 28^{\prime} \mathrm{S}, 20^{\circ} 31^{\prime} \mathrm{E}$, on $Z$. morgsana, leg. A.R. Wood, 12 Oct 1996 (Wood no. 31, I/ III). South Africa, Western Cape Prov., near Homestead, De Hoop Nature Reserve, E of Bredasdorp, $34^{\circ} 27^{\prime} \mathrm{S}, 20^{\circ} 24^{\prime} \mathrm{E}$, on Z. morgsana, leg. A.R. Wood, 29 Sep 2000 (Wood no. 332, I/III). South Africa, Northern Cape Prov., Niewoudtville Nature Reserve, $\mathrm{W}$ of Niewoudtville, $31^{\circ} 21^{\prime} \mathrm{S}, 19^{\circ} 08^{\prime} \mathrm{E}$, on Z. morgsana, leg. A.R. Wood, 25 Sep 2004 (Wood no. $594, \mathrm{I} / \mathrm{III})$.

Uromyces eclipsis differs from $U$. dinteri Mennicken, Maier \& Oberw., U. paulshoekensis Mennicken, Maier \& Oberw. and U. trollipi Kalchbr. \& McOwan by its demicyclic life cycle comprising an aecial stage while the latter species are only known with uredinia and telia. In addition, $U$. paulshoekensis and U. trollipi have smaller teliospores than $U$. eclipsis. The teliospores of $U$. dinteri are very similar to U. eclipsis. U. namaqualandus Mennicken, Maier \& Oberw. is only known with teliospores which are narrower than in the present species and have considerably thicker inner and outer wall layers.

Observations made by Alan R. Wood (personal communication) in specimens from De Hoop Nature Reserve indicate that the witches' brooms induced by U. eclipsis are perennial as new growth bearing rust sori restarts on them after defoliation during the driest season of the year.

The status of Uredo zygophylli Henn. and U. zygophylli Jacz. (= U. zygophyllina Sacc.)

Material examined: Uredo zygophylli Henn. Egypt, on Zygophyllum decumbens Delile, leg. Ehrenberg, May of year? (probably between 1820 and 1825, when C.G. Ehrenberg travelled through North Africa and western Asia). (Holotype, B 700007286, II/[III]). U. zygophyllina Jacz. Algeria, Biskra, on Z. cornutum Coss. Gift from Jaczewski to Ed. Fischer (ZT Myc 644). U. zygophyllina Sacc. Algeria, Biskra, on calcareous hills near Hamman Salahin, on Z. cornutum, leg. G. Schweinfurth, Apr 1901 (Sydow, Uredineen no. 2296. ZT Myc 645, II).

Uredo zygophylli was described by Hennings (1893) from Egypt. Later in the same year U. zygophylli Jacz. was described from Algeria. Saccardo (1895) stated that $U$. zygophylli Jacz. was probably different from $U$. zygophylli Henn. ("videtur diversa ab U. zygophylli Henn.") and proposed for it the new name U. zygophyllina. Sydow and Sydow (1924) regarded U. zygophylli Jacz. and $U$. zygophyllina as synonyms of $U$. zygophylli Henn. Mennicken et al. (2005) followed the view of Saccardo and kept U. zygophyllina apart from U. zygophylli Henn. which they considered to be the uredinial state of Urom. dinteri.

I cannot find important differences between $U$. zygophylli Henn. and U. zygophylli Jacz. though the urediniospores are slightly smaller in the latter (Table 3).
Differences occur, however, between U. zygophylli Henn. and Urom. dinteri whose urediniospores have germ pores "without papillae" (Mennicken et al. 2005) while in $U$. zygophylli the pores are covered by conspicuous bullate caps. Therefore, I agree with Sydow and Sydow (1924) that U. zygophylli Henn. and U. zygophylli Jacz. represent the same rust species for which U. zygophyllina is another synonym.

In the specimen of $U$. zygophylli kept in Z+ZT (ZT Myc 644, sub U. zygophyllina), teliospores of Uromyces were discovered which were different from Urom. dinteri (Table 3). They were smaller and had thinner wall layers (inner layer 4-6 $\mu \mathrm{m}$ vs 5-8(10) $\mu \mathrm{m}$, outer layer 3-4 vs up to $5 \mu \mathrm{m}$ ). This and the observable differences between the urediniospores indicate that $U$. zygophylli Henn. belongs to a teleomorphic species different from Urom. dinteri. As teliospores of Uromyces species on Zygophyllum appear to be variable and as some of the described species are difficult to distinguish a new species will not be described in ZT Myc 644 without having studied the variability within this group on more material.

Acknowledgements Field work was carried out in collaboration with Anja Rössel and Elisabeth Uhlmann whose companionship and help are gratefully acknowledged. The field stays were funded by the German Ministry of Education and Research (BMBF) in the course of the BIOTA research project (subproject S03b). The Western Cape Nature Conservation Board in South Africa is thanked for issuing collecting and export permits, and the curators and directors of B, PREM, PUR, TUB, VPRI for the loan of specimens. Last but not least I thank two anonymous reviewers for helpful comments and corrections.

\section{References}

Berndt R (2008a) The rust mycobiota of southern Africa: species richness, composition and affinities. Mycol Res 112:463-471, doi:10.1016/j.mycres.2007.05.005

Berndt R (2008b) The rust fungi (Uredinales) on ferns in South Africa. Mycol Prog 7:7-19, doi:10.1007/s11557-007-0548-7

Berndt R, Uhlmann E (2006) New species, reports, observations and taxonomical changes of southern African rust fungi. Mycol Prog 5:154-177, doi:10.1007/s11557-006-0510-0

Cowling RM, Richardson DM, Pierce SM (eds) (1997) Vegetation of Southern Africa. Cambridge University Press, Cambridge

Cunningham GH (1931) The rust fungi of New Zealand. John McIndoe, Dunedin, New Zealand

Doidge EM (1927) A preliminary study of the South African rust fungi. Bothalia 2:1-228

Doidge EM (1948) South African rust fungi, part V. Bothalia 4:895918

Doidge EM (1950) The South African fungi and lichens to the end of 1945. Bothalia 5:1-1094

Eboh D (1984) A taxonomic survey of Nigerian rust fungi: Uredinales Nigerianensis-III. Mycologia 76:179-189, doi:10.2307/3793093

Gäumann E (1959) Die Rostpilze Mitteleuropas. Beiträge zur Kryptogamenflora der Schweiz 12. Büchler, Bern

Gjærum HB (1988) Rust fungi (Uredinales) on Poaceae, mainly from Africa. Mycotaxon 31:351-378 
Govaerts R, Ruhsam M, Andersson L, Robbrecht E, Bridson D, Davis A, Schanzer I, Sonké B (without date). World Checklist of Rubiaceae. The Board of Trustees of the Royal Botanic Gardens, Kew. Published on the Internet; http:/www.kew.org/ wcsp/rubiaceae/ (accessed 17 Nov 2008)

Hennings P (1893) Fungi aethiopico-arabici I. Bull Herbier Boissier 1 (3): $97-122$

Holm L (1973) Notes on some East African rusts. Sven Bot Tidskr 67:253-256

Holmgren PK, Holmgren NH, Barnett LC (1990) Index Herbariorum, Part I, 8 edn. The New York Botanical Garden, New York

Khan SA, Razafimandimbison SG, Bremer B, Liede-Schumann S (2008) Phylogeny and biogeography of the African genus Virectaria Bremek. (Sabiceeae s. 1., Ixoroideae, Rubiaceae). Plant Syst Evol 275:43-58, doi:10.1007/s00606-008-0053-8

Klebahn H (1914) Kryptogamenflora der Mark Brandenburg, Vol. Va. Pilze III (Uredineen). Gebr. Bornträger, Leipzig

Laundon GF (1963a) Rust fungi I. On Acanthaceae. Mycol Pap 89:189

Laundon GF (1963b) Rust fungi II. On Aceraceae, Actinidiaceae, Adoxaceae and Aizoaceae. Mycol Pap 91:1-17

Linder HP (2003) The radiation of the Cape flora, southern Africa. Biol Rev Camb Philos Soc 78:597-638, doi:10.1017/ S1464793103006171

McAlpine D (1906) The rusts of Australia. Dept. of Agriculture, Victoria. The Government Printer, Melbourne

Mennicken M, Oberwinkler F (2004) A contribution to the rust flora (Uredinales) of southern Africa, with an emphasis on South Africa. Mycotaxon 90:1-28

Mennicken M, Maier W, Oberwinkler F (2005) A contribution to the rust flora (Uredinales) on Zygophylloideae (Zygophyllaceae) in Africa. Mycotaxon 91:39-48

Morris MJ, Wingfield MJ, Walker J (1988) First record of a rust on Acacia mearnsii in southern Africa. Trans Br Mycol Soc 90:324327

Moss EH (1926) The uredo stage of the Pucciniastreae. Ann Bot (Lond) 40:813-849
Moss EH (1928) The uredinia of Cronartium comandrae and Melampsora medusae. Mycologia 20:36-40, doi:10.2307/ 3753804

Puff C (1986) Rubiaceae, Rubioideae (second part): Paederieae, Anthospermeae, Rubieae. In: Leistner OA (ed) Flora of southern Africa vol. 31, pt. 1, pp 1-79

Saccardo PA (1895) Sylloge Fungorum vol. XI, suppl. univ. pars III, Padova

Sydow P, Sydow H (1904) Monographia Uredinearum, Vol. I. Puccinia. Gebr. Bornträger, Leipzig

Sydow P, Sydow H (1924) Monographia Uredinearum, Vol. IV. Uredineae Imperfectae. Gebr. Bornträger, Leipzig

The International Plant Names Index (2004) Published on the Internet http://www.ipni.org (accessed 18 Jan 2008)

Van Reenen M (1995) An annotated list of Urediniomycetes (rust fungi) from South Africa 1: Melampsoraceae and Pucciniaceae, excluding Puccinia and Uromyces. Bothalia 25:173-181

Viégas AP (1960) Uma ferrugem do saguaragi. Bragantia 19:101-103

Viennot-Bourgin G (1970) Une nouvelle espèce d'Uredo de l'île de la Nouvelle-Amsterdam. Rev Mycologie 34:340-342

Wood AR (2006) New and interesting records of southern African rust fungi (Uredinales). S Afr J Bot 72:534-543, doi:10.1016/j. sajb.2006.02.002

Wood AR (2007) Rust fungi (Uredinales) on Grewia species (Tiliaceae) in South Africa, with Uredopeltis atrides comb. nov. the new name for Ravenelia atrides. Mycol Prog 6:93-99, doi:10.1007/s11557-007-0528-y

Wood AR, Crous PW (2005) Morphological and molecular characterization of Endophyllum species on perennial asteraceous plants in South Africa. Mycol Res 109:387-400, doi:10.1017/ S0953756204002175

Wurth T (1905) Rubiaceen bewohnende Puccinien vom Typus der Puccinia galii. Centralblatt für Bakteriologie (II. Abt.) 14: 209224, 309-320

Yen J-M (1975) Étude sur les champignons parasites du sud-est asiatique. XXIV. Les Urédinées de Formose. Rev Mycologie $39: 251-267$ 